\title{
KAJIAN MEDIA PEMBELAJARAN BERDASARKAN KECENDERUNGAN GAYA BELAJAR PESERTA DIDIK SD/MI
}

\author{
Fita Mustafida ${ }^{1}$
}

\begin{abstract}
Achievement of learning depends on process learning that done. The determinant factor is teacher. Teacher has important role in the learning process in the school or Islamic School. Beside teacher, students also influences, because student is the subject of learning. Because the essence of learning is a process of communicating; is the process of transferring message (Subject Matter) from the source of message (teacher) to the receiver (students). To avoid the fault in the transferring knowledge, needed a media to transferring message from the sender to the receiver that called by media of learning.

By using media of learning suggested to makes more easily for student to receive knowledge well, so that there is no misunderstanding when receive the message from teacher. The ability of teacher to determine the media is very important and needed. Teacher must selective to determine the media of learning that used, because not all media of learning appropriate with condition. Teacher must choose media of learning that appropriate with context/needs, both of material and students.
\end{abstract}

Keywords: Media of learning, Style of learning.

\section{A. Pendahuluan}

Tingkah laku individu merupakan bentuk ekspresi untuk memenuhi kebutuhan. Demikian juga dengan kegiatan sekolah yang merupakan salah satu manifestasi pemenuhan kebutuhan-kebutuhan individu tersebut. Sebagai guru perlu mengenal dan memahami tingkat kebutuhan peserta didiknya, sehingga dapat membantu dalam pemenuhan kebutuhan mereka melalui berbagai aktivitas kependidikan, termasuk aktivitas pembelajaran.

Menurut Sanjaya (2007:457) pembelajaran diartikan sebagai proses komunikasi yang melibatkan tiga komponen pokok, yaitu pemberi pesan (guru), penerima pesan (peserta didik), dan pesan itu sendiri yang berupa materi pelajaran. Agar pesan yang disampaikan guru dapat diterima

1 Dosen Tetap Fakultas Agama Islam Universitas Islam Malang (UNISMA) Jl. Mayjen Haryono 193 Malang 65144, Telp: 0341-551932, Fax: 0341-552249. 
dengan baik oleh peserta didik, maka diperlukan kemampuan guru menciptakan kegiatan pembelajaran yang memudahkan siswa belajar. Karena pada hakekatnya pembelajaran terjadi jika mampu membuat siswa belajar. Untuk mencapai tujuan tersebut, diantara upaya yang dapat dilakukan guru adalah menggunakan media pembelajaran. Dengan penggunaan media pembelajaran, diharapkan mampu memudahkan proses komunikasi (guru-siswa), sehingga informasi yang disampaikan guru dapat diterima dengan baik oleh siswa, tidak ada kesalah pahaman, bahkan kegagalan.

Media pembelajaran sendiri diartikan sebagai segala sesuatu yang dapat digunakan untuk menyalurkan pesan pengirim (guru) kepada penerima (peserta didik), sehingga dapat merangsang pikiran, perasaan, perhatian, dan minat siswa yang menjurus ke arah terjadinya proses belajar. Penggunaan media pembelajaran dengan tepat diharapkan dapat memberikan dasar pengalaman kongkret, mempertinggi perhatian siswa, memberikan realitas, memberikan hasil belajar permanen, menambah perbendaharaan non verbalistik, dan memberikan pengalaman baru, Sanjaya (2007:459). Melihat pentingnya media dalam pembelajaran tersebut, maka kemampuan guru dalam menentukan media pembelajaran yang tepatpun mutlak diperlukan. Ada banyak pilihan media pembelajaran, namun tidak semua media pembelajaran itu cocok digunakan, tetapi harus disesuaikan dengan kebutuhan (tujuan, materi, dan peserta didik).

Selain pengoptimalan media pembelajaran, guru juga harus mengenal betul karakter peserta didiknya. Dengan mengenali karakter siswa, guru dapat mengidentifikasi kebutuhan-kebutuhan mereka. Sehingga memudahkan dalam menentukan langkah-langkah pembelajaran yang sesuai dengan kebutuhan mereka. Dalam Quantum Teaching dikenal dengan azas "Bawalah dunia mereka ke dunia kita dan antarkan dunia kita ke dunia mereka" Bobby DePorter (2001 : 06). Artinya, seorang guru penting memasuki dunia atau kehidupan anak (peserta didik), sehingga dengan pengetahuan tersebut, dapat menuntun dan memudahkan perjalanan siswa dalam meraih hasil belajar yang optimal Saud dan Suherman (2006 : 103). Termasuk diantaranya adalah mengenali bagaimana cara siswa menerima dan memproses informasi atau pelajaran sehingga menjadi sebuah pengetahuan, yang dikenal dengan gaya belajar. Apa pun cara yang dipilih, perbedaan gaya belajar itu menunjukkan cara 
tercepat dan terbaik bagi setiap individu untuk bisa menyerap sebuah informasi dari luar dirinya.

Hasil riset menunjukkan bahwa murid yang belajar dengan menggunakan gaya belajar yang dominan, saat mengerjakan tes, akan mencapai nilai yamg jauh lebih tinggi dibandingkan bila mereka belajar dengan cara yang tidak sejalan dengan gaya belajar mereka Machmudah , rosyidi (2008:01). Menurut Agus priyatmono (2002) mengenali gaya belajar siswa sangat diperlukan, hal tersebut dikarenakan tidak semua siswa memproses informasi dalam pembelajaran dengan cara yang sama. Ada yang biasa belajar untuk membentuk pengetahuan dengan menggunakan indra penglihatan, ada juga yang biasa belajar dengan mendengarkan dan sebagainya. Kebiasaan belajar yang berlangsung lama ini menghasilkan sebuah kebiasaan belajar dan membentuknya menjadi sebuah gaya belajar, Uno (2006:143\&158). Sejalan dengan pendapat di atas, Deporter mendefinisikan gaya belajar sebagai kombinasi dari bagaimana seseorang menyerap dan kemudian mengatur serta mengolah informasi Bobbi Deporter (2003: 112). Berdasarkan pengertian tersebut, pemahaman terhadap gaya belajar siswa tidak bisa dianggap sepele. Gaya belajar siswa berpengaruh terhadap bagaimana siswa menyerap informasi, yang sangat menentukan keberhasilan pembelajaran. Selain itu, dengan pemahaman terhadap gaya belajar siswa, juga dapat memudahkan guru dalam menentukan langkah pembelajaran termasuk pemilihan media pembelajaran yang tepat. Sehingga dapat menerapakan gaya mengajar yang sesuai dengan (kebutuhan) gaya belajar siswa.

Masa usia sekolah dasar (SD/MI) merupakan masa kanak-kanak akhir yang berlangsung dari usia enam hingga sebelas atau dua belas tahun. Peristiwa penting pada masa ini adalah mulai dihadapkan dengan lingkungan masyarakat yang lebih luas diantaranya sekolah. Di sekolah mereka dihadapkan dengan berbagai pengalaman baru baik yang bersifat akademik, maupun non akademik. Dalam perspektif perkembangan kognif Piaget, siswa sekolah dasar (SD/MI) berada pada tahap operasional kongkrit, pada tahap ini anak mengembangkan pemikiran logis, sangat terikat pada fakta-fakta perseptual, anak mampu berfikir logis, tetapi masih terbatas pada objek-objek kongkrit. Di mana dalam proses berfikirnya belum dapat dipisahkan dari dunia kongkrit atau hal-hal yang faktual, mereka juga sudah dapat menggunkan pengalaman sebagai acuan dengan apa yang mereka pahami. (Schunk, 2012: 332). 
Atas dasar tersebut, maka guru dituntut untuk mengembangkan sistem pembelajaran yang sesuai dengan kebutuhan peserta didik, salah satu diantaranya adalah dengan pemanfaatan media pembelajaran berdasarkan kecenderungan gaya belajar peserta didiknya. Apa pun cara yang dipilih, perbedaan gaya belajar itu menunjukkan cara tercepat dan terbaik bagi setiap individu untuk bisa menyerap sebuah informasi dari luar dirinya. Sehingga dalam pemilihan media pembelajaranpun juga harus mempertimbangkan kebutuhan gaya belajar siswa.

\section{B. Kajian Media Pembelajaran}

Belajar merupakan proses terjadinya perubahan tingkah laku melalui pengalaman. Baik pengalaman langsung maupun tidak langsung. Yang dikatakan oleh Bruner (Arsyad, 2009:07) ada tingkatan utama modus belajar, yaitu pengalaman langsung (enactive), pengalaman piktorial/gambar (iconic), dan pengalaman abstrak (symbolic). Tingkatan pengalaman pemerolehan hasil belajar seperti itu digambarkan oleh Dale sebagai suatu proses komunikasi (Arsyad, 2009:07). Komunikasi dapat berhasil dengan baik, jika siswa dapat memanfaatkan semua alat inderanya. Semakin banyak alat indera yang digunakan untuk menerima dan mengolah informasi semakin semakin besar kemungkinan informasi tersebut dimengerti dan dapat dipertahankan dalam ingatan.

Berdasarkan uraian di atas, maka dalam proses belajar mengajar sebaiknya terjadi variasi aktivitas yang melibatkan semua alat indera pebelajar (peserta didik). Semakin banyak alat indera yang terlibat untuk menerima dan mengolah informasi (isi pelajaran), semakin besar kemungkinan isi pelajaran tersebut dapat dimengerti dan dipertahankan dalam ingatan pebelajar. Jadi agar pesan-pesan dalam materi yang disajikan dapat diterima dengan baik, maka pengajar harus berupaya menampilkan stimulus yang dapat diproses dengan berbagai indera pebelajar. Pengertian stimulus dalam hal ini adalah suatu "perantara" yang menjembatani antara penerima pesan (pebelajar) dan sumber pesan (pengajar) agar terjadi komunikasi yang efektif.

Dalam (Supriatna, 2009). Pembelajaran diartikan sebagai sebuah proses komunikasi antara pembelajar, pengajar dan bahan ajar. Komunikasi tidak akan berjalan tanpa bantuan sarana penyampai pesan atau media yang menjadi perantara atau penyampai informasi dari pengirim pesan (guru) kepada penerima pesan (peserta didik), 
Pesan yang akan dikomunikasikan adalah isi pembelajaran yang ada dalam kurikulum yang dituangkan oleh pengajar ke dalam simbolsimbol komunikasi, baik simbol verbal maupun simbol non verbal atau visual. Sehingga istilah pembelajaran lebih menggambarkan usaha guru untuk membuat siswanya belajar. Oleh karena itu, supaya tidak terjadi kesalahan dalam penerimaan pesan/isi pelajaran, maka diperlukan media/perantara yang tepat, sehingga siswa mampu memproses informasi dengan baik, tidak terjadi kesalah pahaman/ salah tafsir yang merupakan hambatan-hambatan komunikasi dalam proses pembelajaran.

Briggs (1977) berpendapat bahwa media pembelajaran adalah sarana fisik untuk menyampaikan isi/materi pembelajaran seperti : buku, film, video dan sebagainya. Sedangkan, National Education Associaton (1969) mengungkapkan bahwa media pembelajaran adalah sarana komunikasi dalam bentuk cetak maupun pandang-dengar, termasuk teknologi perangkat keras. Schramm (1977) mengemukakan bahwa media pembelajaran adalah teknologi pembawa pesan yang dapat dimanfaatkan untuk keperluan pembelajaran. Sementara (Hamalik, 1997) mengatakan media pembelajaran adalah segala bentuk alat komunikasi yang dapat digunakan untuk menyampaikan pesan atau informasi dari sumber atau narasumber kepada peserta didik dengan tujuan untuk merangsang pikiran, perasaan, minat dan perhatian dalam melaksanakan kegiatan pembelajaran. Dari pendapat di atas disimpulkan bahwa media pembelajaran adalah segala sesuatu yang dapat menyalurkan pesan, dapat merangsang fikiran, perasaan, dan kemauan peserta didik sehingga dapat mendorong terciptanya proses belajar pada diri peserta didik.

Dalam Sudjana dan Rivai (2002) disebutkan bahwa fungsi media dalam proses belajar siswa, yaitu: 1) dapat menumbuhkan motivasi belajar siswa karena pengajaran akan lebih menarik perhatian mereka; 2) makna bahan pengajaran akan menjadi lebih jelas sehingga dapat dipahami siswa dan memungkinkan terjadinya penguasaan serta pencapaian tujuan pengajaran;3) metode mengajar akan lebih bervariasi, tidak semata-mata didasarkan atas komunikasi verbal melalui kata-kata; dan 4) siswa lebih banyak melakukan aktivitas selama kegiatan belajar, tidak hanya mendengarkan tetapi juga mengamati, mendemonstrasikan, melakukan langsung, dan memerankan. 
Dengan memanfaatkan fungsi di atas maka guru diharapkan dapat mengoptimalkan pemanfaatan media pembelajaran dalam proses belajar mengajar. Sehingga dapat mengajar dengan usaha yang sedikit dengan hasil yang maksimal. Dengan adanya media pembelajaran guru dapat menciptakan berbagai situasi kelas, konsep, ide yang abstrak dan asing menjadi konkrit sehingga mudah dimengerti oleh peserta didik. Selain itu, penggunaan media dapat menanamkan konsep dasar yang benar, konkrit, dan realistis Sudrajat (w. 2010). Sehingga melalui media pembelajaran peserta didik dapat memperoleh konsep dasar yang lebih nyata sehingga tertanam suatu konsep dasar yang benar dan lebih realistis. Dan pastinya sangat membantu dalam memudahkan siswa dalam menerima materi pelajaran, termasuk siswa SD/MI yang masih berada pada tahap berpikir kongkrit.

Rudi Bretz (2003) mengidentifikasi jenis-jenis media berdasarkan tiga unsur pokok yaitu suara, visual, dan gerak. Sedangkan Heinich and Molenda (2005) mengelompokkan media pembelajaran menjadi enam jenis, yaitu: 1) teks, 2) audio (termasuk suara latar, musik, atau rekaman suara dan lainnya), 3) media visual (seperti gambar/foto, sketsa, diagram, bagan, grafik, kartun, poster, papan buletin dan lainnya, 4) Media Proyeksi Gerak (film gerak, film gelang, program TV, video kaset (CD, VCD, atau DVD), 5) Benda-benda Tiruan / miniatur, (Seperti benda-benda tiga dimensi yang dapat disentuh dan diraba oleh siswa), 6) Manusia (termasuk di dalamnya guru, siswa, atau pakar/ ahli di bidang/materi tertentu).

Berdasarkan jenis-jenis media di atas, maka guru harus mampu memilih media mana yang paling tepat digunakan. Karena tidak mungkin semua media diberikan pada waktu yang bersamaan, tetapi disesuaikan dengan kebutuhan. Masing-masing mempunyai kelebihan dan kekurangan, sehingga sebelum menentukan media yang akan digunakan guru harus mempertimbangan prinsip-prinsip dan kriteria pemilihannya. Salah satu diantaranya adalah disesuaikan dengan kebutuhan peserta didik, dalam hal ini kebutuhan cara/gaya belajarnya.

\section{Tinjauan tentang Gaya Belajar (learning Style)}

Belajar dapat diartikan sebagai suatu proses aktif untuk menuju satu arah tertentu yang dapat meningkatkan perbuatan, kemampuan 
atau pengertian baru. Menurut rumusan Gathrie and Brown;.... "learning is always a case of improving same perfornce or gaining same new ability or understanding" (Gathrie, Brown, 1950: 145). Lebih lanjut Ernest R. Hilgard, merinci rumusan belajar sebagai berikut; "learning is the process by which an activity originates or is changes through training procedures wheter in the laboratory or in the natural environment distinguished from changes by faktors not attributabel to training".Hilgard (1968:05). Berdasarkan rumusan tersebut, dapat ditarik suatu pengertian bahwa belajar adalah sesuatu yang dapat meningkatkan perbuatan, kemampuan, atau pengertian baru. Belajar juga dapat diartikan suatu proses yang dapat menghasilkan suatu aktivitas baru melalui pelatihan di laboratorium maupun di lingkungan alam, yang hasil tersebut berbeda dengan hasil yang diperoleh tanpa adanya proses latihan.

Setiap anak merupakan individu yang unik, masing-masing akan melihat dunia dengan "caranya" sendiri. Meskipun melihat ada satu kejadian pada waktu yang bersamaan, tidak menjamin beberapa anak melaporkan hal yang sama. Seringkali yang menjadi pergumulan dalam dunia pendidikan bukan pada masalah apakah anak dapat belajar?, tetapi pada masalah "bagaimana mereka secara alami belajar dengan cara terbaiknya?"

Atas dasar tersebut, maka guru harus memperlakukan peserta didiknya dengan cara yang berbeda pula. Termasuk penggunaan pendekatan, strategi, metode, dan variasi mengajar lain dalam mencapai tujuan pembelajaran. Jika berbagai metode mengajar telah ditetapkan dan tidak menunjukkan hasil yang diharapkan, maka alternatif lain yang dapat dilakukan oleh guru secara individual dalam proses pembelajaran yaitu atas dasar pemahaman terhadap gaya belajar siswa (Nasution:2008:115). Beberapa temuan penelitian melaporkan bahwa kecocokan antara gaya belajar dengan gaya mengajar guru dapat mempengaruhi terhadap hasil belajar. (Moeljadi Pranata:2002:13-23). Dalam literatur lain, Bobbi DePotter dan Hernacki menyebutkan bahwa mengetahui gaya belajar yang berbeda telah membantu para siswa, dengan demikian akan memberi persepsi yang positif bagi siswa tentang cara guru mengajar. Agar aktivitas belajar dapat tercapai sesuai dengan tujuan yang diinginkan, maka gaya belajar siswa harus dipahami oleh guru (DePorter, Bobbi \& Hernacki, Mike:2000:110).

Menurut Nasution gaya belajar atau learning style adalah cara siswa bereaksi dan menggunakan perangsang-perangsang yang diterimanya 
dalam proses belajar (Nasution:2008:93). Sedangkan menurut Winkel (2005:164) gaya belajar merupakan cara belajar yang khas bagi siswa, apapun cara yang dipilih, perbedaan gaya belajar itu menunjukkan cara tercepat dan terbaik bagi setiap individu untuk bisa menyerap sebuah informasi dari luar dirinya. Menurut Bobbi DePorter dan Mike Hernacki gaya belajar merupakan suatu kombinasi dari bagaimana seseorang menyerap, dan kemudian mengatur serta mengolah informasi DePorter, Bobbi \& Hernacki, Mike (2000:110-112). Setiap orang mempunyai gaya pembelajaran yang tersendiri yang berbeda secara individu sebagaimana sidik jari (Gremli dalam Zakaria, 2007 :1). Sedangkan menurut Zaini dalam Sundari (2009:2) gaya belajar adalah karakteristik dan preferensi atau pilihan individu untuk mengumpulkan informasi, menafsirkan, mengorganisasi, merespon, dan memikirkan informasi yang diterima.

Dari pengertian di atas, disimpulkan bahwa gaya belajar adalah cara yang cenderung dipilih seseorang untuk bereaksi dan menggunakan perangsang-perangsang dalam menyerap dan kemudian mengatur serta mengolah informasi pada proses belajar. Dengan perbedaan tersebut guru harus memperlakukan dengan cara yang berbeda pula. Misalkan dalam satu kelas terdapat 25 peserta didik. Dari ke 25 peserta didik tersebut ada yang mudah menerima pelajaran dengan mendengarkan guru menjelaskan, sebagian lagi lebih mudah memahami materi dengan melihat gambar/tayangan seperti film, dsb. Sedangkan sebagian yang lain, lebih mudah menerima informasi dengan melakukan/ terlibat langsung dalam kegiatan belajar mengajar. Seperti menulis, mendemonstrasikan, dll. Untuk memenuhi perbedaan-perbedaan tersebut, maka guru tidak boleh memaksakan diri mengajar dengan metode yang cenderung memudahkan sebagian siswa saja, seperti metode ceramah yang hanya mudah dipahami oleh siswa yang memilikii tipe belajar auditori, tetapi guru harus mampu menciptakan kegiatan pembelajaran yang memudahkan semua siswanya belajar. Oleh karena itu, pemahaman terhadap gaya belajar siswa mutlak dimiliki oleh guru. Supaya dapat menentukan gaya mengajar yang sesuai dengan kebutuhan peserta didiknya, sehingga tujuan pembelajaran dapat tercapai dengan maksimal. 


\section{Macam-macam Gaya Belajar Peserta Didik}

Banyak pendekatan dalam mengklasifikasikan gaya belajar. Tiga diantaranya yang sering digunakan adalah pendekatan berdasarkan preferensi kognitif, profil kecerdasan, dan preferensi sensori. Dari tiga pendekatan tersebut yang sering digunakan di dunia pendidikan kita adalah pendekatan berdasarkan preferensi sensori Adi W. Gunawan (2004:142). Menurut Barbe dan Swassing (dikutip oleh Hartanti dan Arhartanto) pendekatan berdasarkan sensori motor terdiri atas tiga modalitas (gaya belajar), yaitu: visual, auditorial, dan kinestetik (VAK). Pendapat serupa juga dikemukakan oleh Fleming (2002) bahwa terdapat 3 modalitas belajar, yaitu visual, auditorial, dan kinestetik (Hartanti dan Arhartanto: 2003:295-307). Meskipun akhir-akhir ini Fleming memperkenalkan modalitas/gaya belajar tambahan yakni modalitas read/write (baca/tulis).

Pengkategorian ini tidak berarti bahwa individu hanya memiliki salah satu karakteristik gaya belajar tertentu sehingga tidak memiliki karakteristik gaya belajar yang lain. Tetapi merupakan pedoman bahwa individu memiliki salah satu karakteristik yang paling menonjol, sehingga jika siswa mendapatkan rangsangan yang sesuai dalam belajar maka akan memudahkannya untuk menerima pelajaran. Adapun ketiga macam gaya belajar tersebut dibahas sebagai berikut:

\section{a) Gaya belajar visual (belajar dengan cara melihat)}

Gaya belajar visual merupakan gaya belajar melalui melihat sesuatu, misalnya gambar atau diagram dan pertunjukkan, peragaan atau menyaksikan video (Jamaika dalam Sagitasari (2010). Menurut Deporter dan Hernacki (2011), Gaya belajar visual (visual learners) menitikberatkan ketajaman penglihatan. Artinya, bukti - bukti konkret harus diperlihatkan terlebih dahulu agar siswa paham. Siswa yang memiliki gaya belajar visual menangkap pelajaran lewat materi bergambar. Selain itu, siswa memiliki kepekaan yang kuat terhadap warna, disamping mempunyai pemahaman yang cukup terhadap masalah artistik. Hanya saja biasanya memiliki kendala untuk berdialog secara langsung karena terlalu reaktif terhadap suara, sehingga sulit mengikuti anjuran secara lisan dan sering salah mengucapkan kata atau ucapan. Di dalam kelas, anak visual lebih suka mencatat sampai detil-detilnya untuk mendapatkan informasi, sebagian kecil dari mereka berorientasi pada "teks tercetak" dan dapat belajar melalui membaca. 
Ciri-ciri siswa yang lebih dominan memiliki gaya belajar visual misalnya lirikan mata ke atas bila berbicara dan berbicara dengan cepat. Anak yang mempunyai gaya belajar visual harus melihat bahasa tubuh dan ekspresi muka gurunya untuk mengerti materi pelajaran. Siswa cenderung untuk duduk di depan agar dapat melihat dengan jelas. Siswa berpikir menggunakan gambar-gambar di otak dan belajar lebih cepat dengan menggunakan tampilan-tampilan visual, seperti diagram, buku pelajaran bergambar, dan video. Di dalam kelas anak visual lebih suka mencatat sampai detil-detilnya untuk mendapatkan informasi.( Rose Colin dan Nicholl (2002:130)

Menurut Deporter individu yang memiliki kemampuan belajar visual yang baik ditandai dengan ciri - ciri perilaku sebagai berikut:

1) Rapi dan teratur

2) Berbicara dengan cepat

3) Mampu membuat rencana dan mengatur jangka panjang dengan baik

4) Teliti dan rinci

5) Mementingkan penampilan

6) Lebih mudah mengingat apa yang dilihat daripada apa yang didengar

7) Mengingat sesuatu berdasarkan asosiasi visual

8) Sulit menerima instruksi verbal (sering kali siswa minta instruksi secara tertulis)

9) Lebih suka membaca daripada dibacakan

10) Jika sedang berbicara di telepon suka membuat coretan - coretan tanpa arti selama berbicara

11) Lupa menyampaikan pesan verbal kepada orang lain

12) Sering menjawab pertanyaan dengan jawaban singkat "ya" atau "tidak"

13) Lebih tertarik pada bidang seni (lukis, pahat, gambar) daripada musik.

14) Lebih suka mendemonstrasikan sesuatu daripada berpidato atau berceramah 
15) Sering kali mengetahui apa yang harus dikatakan, tetapi tidak pandai menuliskan dalam kata - kata

16) Kadang - kadang kehilangan konsentrasi ketika ingin memperhatikan

17) Mengerti dengan baik mengenai warna

18) Pembaca cepat dan tekun. (Deporter dan Hernacki (2011).

\section{b) Gaya belajar auditorial (belajar dengan cara mendengar)}

Gaya belajar auditorial merupakan gaya belajar melalui mendengar sesuatu seperti suara musik, kaset audio, ceramah kuliah, diskusi, debat dan instruksi atau perintah verbal (Jamaika dalam Sagitasari (2010). Gaya belajar auditorial mempunyai kemampuan dalam hal menyerap informasi dari pendengaran. Metode pembelajaran yang tepat untuk pembelajar model seperti ini harus memperhatikan kondisi fisik dari pembelajar.

Ciri-ciri siswa yang lebih dominan memiliki gaya belajar auditori misalnya lirikan mata ke arah kiri/ kanan, mendatar bila berbicara dan sedang-sedang saja. Untuk itu, guru sebaiknya harus memperhatikan siswanya hingga ke alat pendengarannya. Anak yang mempunyai gaya belajar auditori dapat belajar cepat dengan menggunakan diskusi verbal dan mendengarkan apa yang guru katakan. Anak auditori mencerna makna yang disampaikan melalui tone, suara, pitch (tinggi rendahnya), kecepatan berbicara dan hal-hal auditori lainnya. Informasi tertulis terkadang mempunyai makna yang minim bagi anak auditori. Anak-anak seperti ini biasanya dapat menghafal lebih cepat dengan membaca teks dengan keras dan mendengarkan kaset. Rose Colin dan Nicholl (2002:130)

Jadi, Karakteristik gaya belajar auditorial seperti ini benar-benar menempatkan pendengaran sebagai alat utama menyerap informasi atau pengetahuan. Artinya, kita harus mendengar, baru kemudian kita bisa mengingat dan memahami informasi itu. Menurut (Haryanto, 2011) Karakter pertama orang yang memiliki gaya belajar ini adalah semua informasi hanya bisa diserap melalui pendengaran, kedua memiliki kesulitan untuk menyerap informasi dalam bentuk tulisan secara langsung, ketiga memiliki kesulitan menulis ataupun membaca. 
Individu yang memiliki kemampuan belajar auditorial yang baik ditandai dengan ciri - ciri perilaku sebagai berikut:

1) Mudah terganggu oleh keributan dan suara berisik

2) Menggerakkan bibir dan mengucapkan tulisan di buku ketika membaca

3) Lebih senang mendengarkan (dibacakan) daripada membaca

4) Dapat mengulangi atau menirukan nada, irama dan warna suara

5) Mengalami kesulitan untuk menuliskan sesuatu, tetapi sangat pandai dalam bercerita

6) Lebih menyukai seni musik dibandingkan seni yang lainnya

7) Senang berbicara, berdiskusi, dan menjelaskan sesuatu secara panjang lebar

8) Lebih pandai mengeja/mengucapkan kata - kata dengan keras daripada menuliskannya

9) Lebih suka humor atau gurauan lisan daripada membaca buku humor/komik

10) Mempunyai masalah dengan pekerjaan - pekerjaan yang melibatkan visualisasi seperti memotong bagian - bagian hingga sesuai satu sama lain. (Deporter dan Hernacki, 2011).

Kendala pebelajar auditorial ini adalah anak sering lupa apa yang dijelaskan guru. Sering keliru apa yang disampaikan oleh guru, dan juga sering lupa membuat tugas yang diperintahkan melalui lisan. Siswa yang menyukai gaya belajar auditorial umumnya tidak suka membaca buku petunjuk. Dia lebih suka bertanya untuk mendapatkan informasi yang diperlukannya, Qodriah (2011:11)

\section{c) Gaya belajar kinestetik (belajar dengan cara bergerak, bekerja dan menyentuh)}

Gaya belajar kinestetik merupakan gaya belajar melalui aktivitas fisik dan keterlibatan langsung seperti bergerak, menyentuh dan merasakan atau mengalami sendiri. Gaya belajar kinestetik merupakan aktivitas belajar dengan cara bergerak, bekerja dan menyentuh. Pembelajar tipe ini mempunyai keunikan dalam belajar selalu bergerak, aktivitas panca 
indera, dan menyentuh. Belajar melalui aktivitas fisik dan keterlibatan langsung, bergerak, menyentuh dan merasakan/mengalami sendiri (Rose, Colin \& Malcolm J. Nicholl:2002:130-131).

Berdasarkan pengertian di atas, maka dapat disimpulkan bahwa tipe pembelajar kinestetik cenderung mudah menerima dan mengolah informasi melalui serangkaian aktivitas yang menggerakkan sebagian / seluruh anggota tubuh dan mempraktekkan hal-hal yang dipelajari. Pembelajar tipe ini sulit untuk duduk diam berjam - jam karena keinginan siswa untuk beraktivitas sangatlah kuat. Sehingga dalam proses pembelajaran mengharuskan individu yang bersangkutan menyentuh sesuatu yang memberikan informasi tertentu agar ia bisa mengingatnya. Adapun karakter anak yang memiliki gaya belajar ini menurut (Haryanto, 2011) adalah menempatkan tangan sebagai alat penerima informasi utama agar bisa terus mengingatnya. Hanya dengan memegangnya saja, seseorang yang memiliki gaya ini bisa menyerap informasi tanpa harus membaca penjelasannya.

Individu yang memiliki kemampuan belajar kinestetik yang baik ditandai dengan ciri - ciri perilaku sebagai berikut:

1) Berbicara dengan perlahan

2) Menanggapi perhatian fisik, banyak gerak fisik

3) Berdiri dekat ketika sedang berbicara dengan orang lain

4) Belajar melalui praktek langsung atau manipulasi

5) Menghapalkan sesuatu dengan cara berjalan atau melihat langsung

6) Menggunakan jari untuk menunjuk kata yang dibaca ketika sedang membaca

7) Tidak dapat duduk diam di suatu tempat untuk waktu yang lama

8) Sulit membaca peta kecuali pernah ke tempat tersebut

9) Pada umumnya tulisannya jelek

10) Menyukai kegiatan atau permainan yang menyibukkan (secara fisik)

11) Banyak menggunakan isyarat tubuh. (Deporter dan Hernacki, 2011). 
Berdasarkan ketiga tipe gaya belajar siswa di atas, guru dapat menjadikannya sebagai salah satu pertimbangan dalam menentukan strategi/metode pembelajaran yang digunakan dalam kegiatan pembelajaran, termasuk penggunaan media pembelajaran yang tepat. Semisal, untuk siswa yang memiliki kecenderungan gaya belajar visual (belajar dengan melihat), guru dapat menggunakan media gambar untuk merangsang terjadi proses belajar, sedangkan siswa yang memiliki kecenderungan auditorial (belajar dengan mendengar), guru dapat mengajar dengan memanfaatkan media audio, seperti rekaman, musik, lagu-lagu sebagai salah satu langkah untuk membuat belajar. Bagi siswa yang memiliki kecenderungan gaya belajar kinestetik (belajar dengan cara bergerak) guru dapat memfasilitasi dengan menggunakan media yang dapat disentuh dan diraba oleh siswa, seperti patung, boneka, torso dan sebagainya.

\section{E. Media Pembelajaran yang sesuai dengan kecenderungan gaya belajar peserta didik SD/MI}

Prinsip belajar siswa (SD/MI) harus mencangkup 3 aspek belajar kognitif (pengetahuan), afektif (perasaan), dan psikomotor (cara melakukan), juga dengan 3 modalitas belajar dari anak yaitu visual (gambar), auditorial (diskusi), dan kinestetik (meragakan), selain itu anak usia (SD/MI) juga akan lebih mudah jika mereka belajar bersama teman sebayanya dengan berkelompok sehingga dapat menimbulkan interaksi juga dengan didampingi orang yang lebih ahli.

Menurut Sadiman, faktor yang perlu dipertimbangkan dalam pemilihan media adalah tujuan instruksional yang ingin dicapai, karakteristik siswa, jenis rangsangan belajar yang diinginkan, keadaan latar belakang dan lingkungan siswa, situasi kondisi setempat dan luas jangkauan yang ingin dilayani (Sadiman, 83-84). Senada dengan pendapat tersebut, Ahmad Rohani dalam bukunya "Media Instruksional Edukatif" mengatakan bahwa salah satu yang perlu diperhatikan dalam pemilihan media pembelajaran adalah keadaan peserta didik (Ahmad Rohani, 1997: 72). Pertimbangan terhadap karakteristik peserta didik dianggap penting, dikarenakan inti dari pembelajaran adalah membuat siswa belajar, sehingga untuk menjadikan siswa belajar hal pertama yang harus diperhatikan adalah mengetahui bagaimana cara siswa 
menerima dan memproses informasi sehingga terjadi perubahan yang menjadikannya belajar.

Dengan adanya "keunikan" cara belajar peserta didik tersebut, maka dalam memilih media pembelajaranpun harus disesuaikan. Agar keseluruhan peserta didik yang memiliki modalitas atau cara belajar yang berbeda tersebut mampu menerima informasi yang disampaikan guru dengan baik.

Berikut contoh media pembelajaran yang dapat digunakan berdasarkan kecenderungan gaya belajar peserta didik, khususnya di $\mathrm{SD} / \mathrm{MI}$.

1) Media pembelajaran untuk mempermudah proses belajar peserta didik visual

Oleh karena pembelajar visual lebih mudah belajar dengan melihat, maka media pembelajaran yang cocok bagi pembelajar ini adalah media pembelajaran yang mengandalkan indra penglihatan/ materi visual. Seperti foto, ilustrasi, flashcard, gambar pilihan dan potongan gambar, film bingkai grafik, bagan, diagram, poster, peta, kartun, poster, papan buletin dan lainnya. Selain itu, guru juga dapat mengajak peserta didiknya mengilustrasikan ide - ide ke dalam sebuah gambar.

2) Media pembelajaran untuk mempermudah proses belajar peserta didik auditorial

Berbeda dengan pembelajar visual yang mengandalkan penglihatan, tipe pembelajar auditorial ini mengandalkan indra pendengaran untuk belajar, sehingga media pembelajaran yang cocok digunakan adalah media audio (media dengar), seperti radio, tape recorder, telepon, laboratorium bahasa, dll. Selain penggunaan media dengar tersebut guru juga dapat mengkolaborasi media dengan metode pembelajaran yang melibatkan indra pendengaran seperti: mendiskusikan ide dengan anak secara verbal, menggunakan musik untuk mengajarkan anak mengajak peserta didik merekam materi pelajarannya ke dalam kaset dan mendorongnya untuk mendengarkannya sebelum tidur. 
3) Media pembelajaran untuk mempermudah proses belajar peserta didik kinestetik

Tipe pembelajar ini mengolah informasi melalui serangkaian aktivitas yang menggerakkan sebagian / seluruh anggota tubuh dan mempraktekkan hal-hal yang dipelajari, sehingga kegiatan memegang, menyentuh dengan gerakan badan atau tangan akan memudahkannya untuk belajar. Sehingga media pembelajaran yang tepat digunakan adalah media yang dapat diraba/disentuh seperti benda-benda tiga dimensi yang dapat disentuh dan diraba oleh siswa, menggunakan komputer atau kalkulator, boneka tangan, menyusun kliping bergambar, dan sebagainya.

Berdasarkan contoh-contoh media sebagaimana di atas, secara sederhana dapat ditampilkan sebagaimana tabel berikut:

\section{CONTOH MEDIA PEMBELAJARAN BERDASARKAN KECENDERUNGAN GAYA BELAJAR PESERTA DIDIK:}

\begin{tabular}{|l|l|}
\hline Gaya Belajar & \multicolumn{1}{|c|}{ Media Pembelajaran } \\
\hline Visual & $\begin{array}{l}\text { Materi visual seperti gambar - gambar, diagram dan peta, kartun, poster, } \\
\text { papan buletin dan lainnya. }\end{array}$ \\
\cline { 2 - 3 } & mengilustrasikan ide - ide ke dalam gambar. \\
\hline Audiotorial & radio, tape recorder, laboratorium bahasa, dan sejenisnya \\
\cline { 2 - 3 } & Diskusikan ide secara verbal \\
\cline { 2 - 3 } & Gunakan musik \\
\cline { 2 - 3 } & Biarkan anak merekam materi pelajarannya ke dalam kaset \\
\hline \multirow{5}{*}{ Kinestetik } & $\begin{array}{l}\text { Ajak anak untuk belajar sambil mengeksplorasikan lingkungannya } \\
\text { (contohnya : ajak dia belajar sambil bersepeda, gunakan objek } \\
\text { sesungguhnya untuk belajar konsep baru). }\end{array}$ \\
\cline { 2 - 3 } & $\begin{array}{l}\text { Aneka media peraga, seperti boneka tangan dan percobaan langsung di } \\
\text { laboratorium, hingga aktivitas luar ruang seperti field trip }\end{array}$ \\
\cline { 2 - 3 } & $\begin{array}{l}\text { Benda-benda Tiruan / miniatur (seperti benda-benda tiga dimensi yang dapat } \\
\text { disentuh dan dirabaoleh siswa). }\end{array}$ \\
\cline { 2 - 3 } & $\begin{array}{l}\text { Menggunakan komputer atau kalkulator, (dengan mengguakan jari-jari anak } \\
\text { selalu bekerja, mereka bisa bereksperimen dengan bentuk dan warna huruf } \\
\text { berbeda saat mengetik di komputer supaya dia lebih terstimulasi. }\end{array}$ \\
\cline { 2 - 3 } & $\begin{array}{l}\text { Anak bisa mewarnai buku catatan pelarajaran atau peta. Kegiatan itu } \\
\text { membuat dia tetap sibuk beraktlvitas yang membuat dia lebih mudah } \\
\text { menyerap pelajaran. }\end{array}$ \\
\hline & $\begin{array}{l}\text { Gunakan warna terang untuk menggaris bawahi hal - hal penting dalam } \\
\text { Bacaan }\end{array}$ \\
\hline
\end{tabular}


Selain contoh klasifikasi media pembelajaran sebagaimana penjelasan di atas, dalam kegiatan pembelajaran guru juga dapat mendesain media yang mampu mengatasi segala keterbatasan, khususnya gaya belajar siswa. Sehingga dalam penerapannya guru dapat menyediakan berbagai jenis media (multi media), Atau bisa dengan cara mengkolaborasikan jenis media pembelajaran, dimana media tersebut mencangkup keseluruhan jenis modalitas belajar siswa, Seperti media boardgame, dengan media tersebut dapat memberikan stimulus belajar melalui rangkaian permainan disertai dengan peraga dan ilustrasi menarik yang diharapkan dapat memudahkan siswa dalam memahami materi pada pelajaran. Karena boardgame dapat di mainkan lebih dari 2 orang atau berkelompok juga memiliki visual sesuai dengan pembelajar visual, selain itu boardgame juga bisa membantu dengan berdiskusi dengan tanya jawab sesuai dengan pembelajar auditory/audio, juga dapat membantu kinestetik dengan peragaan-peragaan yang ada. Selain media boardgame tersebut, guru juga dapat memanfaatkan berbagai media pembelajaran seperti multimedia, mind mapping, projected stiil media (slide; over head proyektor $(\mathrm{OHP})$, in focus) dan projected motion media televisi, film, video (VCD \& $D V D$ ) sebagainya untuk mengatasi keterbatasan, khususnya kebutuhan gaya belajar siswa.

Namun yang terpenting dalam prinsip penggunaan media pembelajaran adalah, kemampuan dalam menggunkan media sehingga dapat membuat siswa belajar. Apapun jenis media yang digunakan, jikalau guru tidak mampu menggunakannya, maka tidak berarti apa-apa. Sebaliknya jika guru mampu menggunakan media dengan baik maka akan memperoleh manfaat sebagaimana dijelaskan di atas. Oleh karena itu, penggunaan metode pembelajaran yang sesuai juga diperlukan, karena media tanpa metode tidak memiliki arti yang signifikan.

\section{F. Kesimpulan}

Proses pembelajaran merupakan proses komunikasi. Dalam proses pembelajaran, media memiliki fungsi sebagai pembawa informasi dari sumber (guru) menuju penerima (siswa). Dengan fungsi ini maka media pembelajaran diharapkan mampu merangsang perhatian, minat, pikiran, dan perasaan siswa dalam kegiatan belajar untuk mencapai tujuan belajar. Media Pembelajaran diartikan sebagai segala sesuatu yang dapat menyalurkan pesan, dapat merangsang fikiran, perasaan, 
dan kemauan peserta didik sehingga dapat mendorong terciptanya proses belajar pada diri peserta didik. Secara umum media pembelajaran dibedakan menjadi tiga, yaitu; media visual, audio, dan kinestetik. Dari jenis tersebut, mengharuskan guru mampu menentukan media apa yang paling tepat digunakan dalam pembelajaran, karena tidak semua media cocok digunakan pada semua keadaan, namun melihat pada konteks / kebutuhan, baik materi maupun kebutuhan peserta didiknya.

Pada hakekatnya pembelajaran terjadi jika mampu membuat siswanya belajar. Oleh karena itu, pemahaman terhadap kebutuhan peserta didik, terutama terkait bagaimana cara siswa menerima dan memproses informasi mutlak dimiliki oleh guru. Sehingga dalam menentukan media pembelajaran yang tepat, harus mempertimbangankan terhadap kecenderungan gaya belajar siswa. Misal, jikalau ada peserta didik yang memiliki cara belajar visual (belajar dengan melihat), guru dapat menggunakan media yang bisa di lihat oleh peserta didiknya (media visual). Seperti: gambar, peta, diagram, dan lain sejenisnya. Jikalau ada peserta didik yang memiliki cara belajar auditorial (belajar dengan mendengar), guru menggunakan media yang bisa di dengar oleh peserta didiknya (media audial). seperti: radio, tape recorder, dan lainnya. Sedangkan bagi peserta didik yang memiliki cara belajar kinestetik (belajar dengan bergerak, dan menyentuh), dapat menggunakan media pembelajaran yang memungkinkan peserta didiknya untuk bergerak. Seperti boneka tangan dan percobaan langsung di laboratorium, hingga aktivitas luar ruang seperti field trip, benda-benda tiga dimensi yang dapat disentuh dan dirabaoleh siswa, dan sebagainya.

\section{DAFTAR PUSTAKA}

Arsyad, Azhar. 2009. Media Pembelajaran. Jakarta: Rajawali Pers.

Colin Rose dan Malcolm J. Nicholl. Accelerated learning for the 21st century: [ter. Dedy Ahimsa cara belajar cepat abad XXI], Bandung : Nuansa.

Dimyati, Mudjiono. 2006. Belajar dan pembelajaran . Jakarta: Rineka Cipta.

Dadang Supriatna, M. Ed, 2009. Pengenalan Media Pembelajaran. Journal.

Fleming, Neil \& Baume, David. 2006. Learning StyleAgain: VARKing 
Fita Mustafida - Kajian Media Pembelajaran Berdasarkan ...

Up The Right Tree!. Jurnal Akademik vol 11, No.137. New Zeeland.

Gathrie, Edwin and Francis F. Brown. 1950. Educational Psychology, New York: Press Company.

Gunawan, W Adi.. 2004. Genius Learning Strategy. Petunjuk praktis untuk menerapkan Accelerated Learning. Jakarta: Gramedia Pustaka Utama.

Hilgard R, Ernest. 1968. Theories of Learning, New York: Appleton Century CroftsInc.

Imam, Saeful. 2009. Kenali Gaya Belajar Anak Anda.[online]. Tersedia :http//www.tabloid-nakita.com/ [01April 2010]

Machmudah,Umi dan Abdul Wahab Rosyidi. 2008. Active Learning dalam Pembelajaran Bahas Arab. Malang: UIN/Malang Press.

Moeljadi Pranata Jurnal. Nirmana Vol. 4, No. 1, Januari 2002: 13 - 23; Universitas Kristen Petra.

Nasution J. Mursell S. 2008. Mengajar dengan Sukses. Jakarta : Bumi Aksara.

Rohani, Ahmad. (1997). Media Instruksional Edukatif. Jakarta: Rineka Cipta.

Rumini, Sri, Sri Sundari. 2004. Perkembangan Anak dan Remaja. Jakarta : Rineka Cipta.

Sadiman, Arief S (dkk). 2007. Media Pendidikan. Jakarta : Raja Grafindo Persada.

Sudjana, Nana dan Ahmad Rivai. 2002. Media Pengajaran. Bandung: Sinar Baru Algensindo

Saud, S.U. dan Suherman, Ayi. 2006. Inovasi Pendidikan. Bandung: UPI PRESS.

Sudjana dan Rivai. 2002. Media Pendidikan. Jakarta: Balai Pustaka.

Uno, Hamzah B. 2008. Orientasi Baru dalam Psikologi Pembelajaran. Jakarta : Bumi Aksara 
